\title{
Case Series Study of Melioidosis, Colombia
}

\author{
José Y. Rodríguez, Soraya E. Morales-López, \\ Gerson J. Rodríguez, Carlos A. Álvarez-Moreno, \\ Kelin Esquea, Heidy Pinzon, Luis R. Ramirez, \\ Lilian Moreno, Walter Ocampo, Martha L. Cepeda
}

We report 7 cases of melioidosis in Colombia and comparision of 4 commercial systems for identifying Burkholderia pseudomallei. Phoenix systems were not a definitive method for identifying $B$. pseudomallei. For accurate identification, we recommend including this bacterium in the library databases of matrix-assisted laser desorption/ionization mass spectrometry systems in Latin America.

$\mathrm{M}$ elioidosis is an infectious disease caused by Burkholderia pseudomallei, a saprophytic soil bacterium (1). Recently, an increase in cases outside the Asia-Pacific region, including the Americas, has been reported. It is not clear whether this increased number of cases reflects an increase in incidence of this disease or improvements in its identification by microbiological laboratories and research facilities (2).

\section{The Study}

We describe 7 cases of melioidosis in the Caribbean coast region of Colombia among patients who sought emergency services or were referred to 3 hospitals in the city of Valledupar (Figure). None of the patients reported travel abroad. Four patients were admitted during 2015 and 2016; we analyzed the corresponding isolates using 4 commercial methods and a molecular identification method. For the other 3 cases, which were diagnosed in 2014, we reviewed patient medical records and microbiological results. These

Author affiliations: Hospital Rosario Pumarejo de López, Valledupar, Colombia (J.Y. Rodríguez); Centro de Investigaciones Microbiológicas del Cesar (CIMCE), Valledupar (J.Y. Rodríguez, G.J. Rodríguez); Clínica Laura Daniela, Valledupar (J.Y. Rodríguez, K. Esquea); Clínica Médicos LTDA, Valledupar (J.Y. Rodríguez, H. Pinzon); Laboratorios Nancy Flórez García S.A.S., Valledupar (S.E. Moralez-López); Universidad Popular del Cesar, Valledupar (S.E. Moralez-López); Universidad Nacional de Colombia, Bogotá, Colombia (C.A. Álvarez-Moreno); Clínica Universitaria Colombia, Clínicas Colsanitas, Bogotá (C.A. ÁlvarezMoreno); Grupo de Investigaciones Microbiológicas del Cesar, Valledupar (L.R. Ramirez, L. Moreno); Corporación CorpoGen, Bogotá (W. Ocampo, M.L. Cepeda)

DOI: https://doi.org/10.3201/eid2508.170786 isolates were not available. The study was approved by the ethics committees of Clinica Laura Daniela, Clínica Médicos, and Instituto Cardiovascular del Cesar.

Of the 7 patients, $6(86 \%)$ were men; 2 patients were admitted to the intensive care unit (Table 1). The most common clinical presentation was bacteremic pneumonia (in 4 patients); 5 patients had a history of diabetes.

The 4 strains isolated in 2015 and 2016 were identified as B. pseudomallei by Vitek Compact 2 (bioMérieux, https://www.biomerieux.com) and Microscan (Walkaway Beckman Coulter, https://www.beckmancíoulter.com) but as B. cepacia by Phoenix (Becton Dickinson, http://www. bd.com) and as $B$. thailandesis by MALDI Biotyper v3.1 matrix-assisted laser desorption/ionization time-of-flight (MALDI-TOF) mass spectrometry (Bruker Daltonics, https://www.bruker.com). Internal transcribed spacer (ITS) DNA sequencing identified all the isolates as B. pseudomallei. Sequences of these 4 isolates were submitted to GenBank (accession nos. KX898558, KY659330, KY996759, and KY659331). According to patient medical records, the 3 isolates from 2014 were identified as B. pseudomallei using the Vitek or Microscan system or both (Table 2).

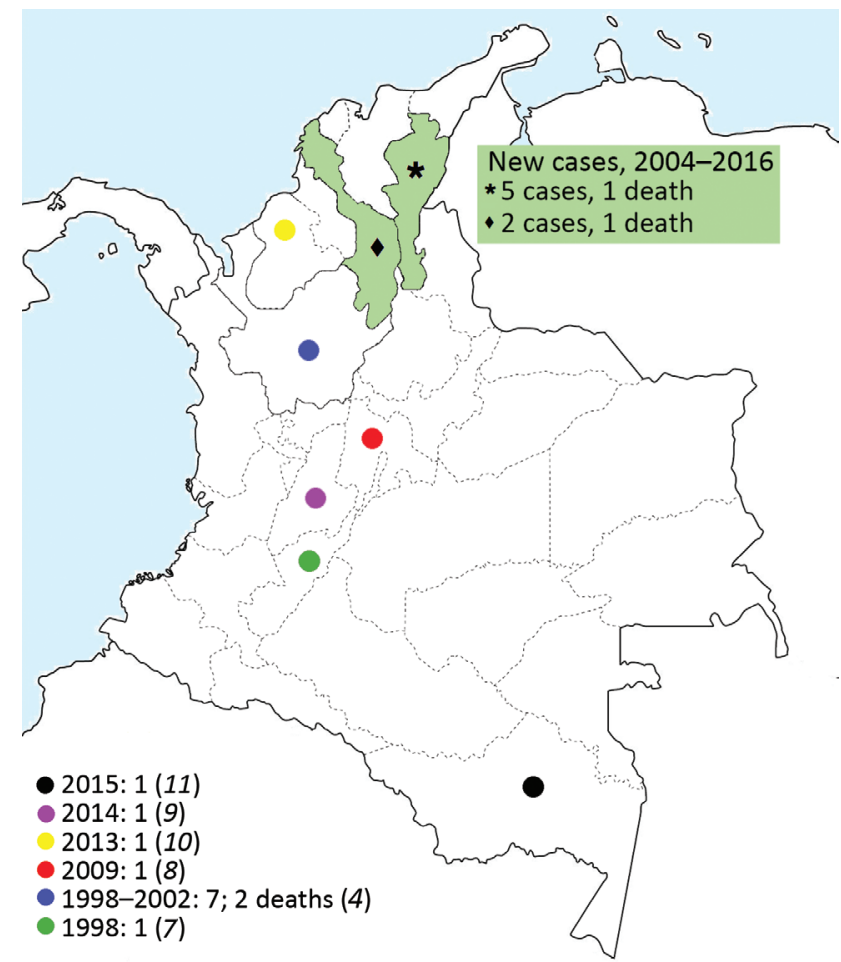

Figure. Geographic locations of 7 reported cases of melioidosis in Colombia. 
Table 1. Epidemiologic and demographic characteristics, underlying conditions, clinical manifestations, and outcomes of patients with melioidosis in the Caribbean coast region of Colombia*

\begin{tabular}{|c|c|c|c|c|c|c|c|c|c|}
\hline $\begin{array}{l}\text { Patient } \\
\text { no. }\end{array}$ & $\begin{array}{l}\text { Patient } \\
\text { age, yl } \\
\text { sex }\end{array}$ & $\begin{array}{l}\text { Medical history and } \\
\text { risk factors }\end{array}$ & $\begin{array}{c}\text { Clinical } \\
\text { manifestation }\end{array}$ & Type of sample & $\begin{array}{l}\text { Empirical } \\
\text { treatment }\end{array}$ & $\begin{array}{l}\text { Appropriate } \\
\text { treatment } \\
\text { (duration) }\end{array}$ & ICU & Outcome & Relapse \\
\hline 1 & $72 / \mathrm{M}$ & $\begin{array}{l}\text { Diabetes, arterial } \\
\text { hypertension }\end{array}$ & $\begin{array}{l}\text { Bacteremic } \\
\text { pneumonia }\end{array}$ & $\begin{array}{l}\text { Blood culture, } \\
\text { urine culture, } \\
\text { endotracheal } \\
\text { aspirate }\end{array}$ & $\begin{array}{c}\text { TZP + } \\
\text { CLR }\end{array}$ & $\begin{array}{l}\text { IP: MER + } \\
\text { TMP/SMX (14 } \\
\text { d); EP: NA }\end{array}$ & Yes & Died & NA \\
\hline 2 & $60 / \mathrm{F}$ & $\begin{array}{l}\text { Diabetes, arterial } \\
\text { hypertension, } \\
\text { minor head injury } \\
\text { with open scalp } \\
\text { wound }\end{array}$ & $\begin{array}{l}\text { Bacteremic } \\
\text { SSTI }\end{array}$ & $\begin{array}{l}\text { Wound } \\
\text { secretion, blood } \\
\text { culture }\end{array}$ & $\begin{array}{c}\mathrm{CFZ}+ \\
\mathrm{CLI}\end{array}$ & $\begin{array}{l}\text { IP: MER }(10 \mathrm{~d}) \text {; } \\
\text { EP: TMP/SMX } \\
(3 \mathrm{mo})\end{array}$ & No & Alive & No \\
\hline 3 & 49/M & $\begin{array}{l}\text { Diabetes, leprosy, } \\
\text { erythema nodosum } \\
\text { leprosum, chronic } \\
\text { use of steroids }\end{array}$ & $\begin{array}{l}\text { Bacteremic } \\
\text { pneumonia }\end{array}$ & $\begin{array}{l}\text { Blood culture, } \\
\text { urine culture, } \\
\text { sputum culture }\end{array}$ & $\begin{array}{c}\text { TZP + } \\
\text { CLR }\end{array}$ & $\begin{array}{l}\text { IP: MER }(10 \mathrm{~d}) \text {; } \\
\text { EP: TMP/SMX } \\
(6 \mathrm{mo})\end{array}$ & No & Alive & No \\
\hline 4 & 71/M & $\begin{array}{c}\text { Arterial } \\
\text { hypertension, } \\
\text { multiple myeloma, } \\
\text { bone marrow } \\
\text { transplant, chronic } \\
\text { use of steroids and } \\
\text { thalidomide }\end{array}$ & $\begin{array}{l}\text { Bacteremic } \\
\text { pneumonia }\end{array}$ & Blood culture & $\begin{array}{l}\text { TZP + } \\
\text { DOX }\end{array}$ & $\begin{array}{l}\text { IP: MER (14 d); } \\
\text { EP: TMP/SMX } \\
(3 \mathrm{mo})\end{array}$ & No & Alive & No \\
\hline 5 & 66/M & $\begin{array}{c}\text { Diabetes, } \\
\text { arterial hypertension }\end{array}$ & $\begin{array}{l}\text { Bacteremic } \\
\text { pneumonia }\end{array}$ & $\begin{array}{l}\text { Blood culture, } \\
\text { endotracheal } \\
\text { aspirate }\end{array}$ & TZP & NA & Yes & Died & NA \\
\hline 6 & $56 / \mathrm{M}$ & $\begin{array}{l}\text { Diabetes, chronic } \\
\text { renal failure }\end{array}$ & UTI & Urine culture & TZP & $\begin{array}{c}\text { IP: MER }(10 \mathrm{~d}) \text {; } \\
\text { EP: TMP/SMX } \\
(3 \mathrm{mo})\end{array}$ & No & Alive & $\begin{array}{c}\text { At } 6 \text { mo: } \\
\text { bacteremia, } \\
\text { UTI, SSTI }\end{array}$ \\
\hline 7 & $54 / \mathrm{M}$ & $\begin{array}{l}\text { Tibia and fibula open } \\
\text { fracture }\end{array}$ & SSTI & $\begin{array}{l}\text { Wound } \\
\text { secretion, blood } \\
\text { culture }\end{array}$ & $\begin{array}{c}\mathrm{CFZ}+ \\
\mathrm{CLI}\end{array}$ & $\begin{array}{l}\text { IP: MER }(10 \mathrm{~d}) ; \\
\text { EP: TMP/SMX } \\
(6 \mathrm{mo})\end{array}$ & No & Alive & No \\
\hline
\end{tabular}

MIC testing was performed using the system available in the institution where the patient was being treated: Microscan Walkaway (isolates 1, 2, 3, 5) and Phoenix systems (isolates 4, $6,7)$. According to published cutoff points for B. pseudomallei (Clinical and Laboratory Standards Institute, https://clsi.org/ standards/products/microbiology/documents $/ \mathrm{m} 45$ ), all isolates were susceptible to trimethoprim/sulfamethoxazole and meropenem, and 2 isolates (isolates 2 and 7) were resistant to ceftazidime (MIC $>16 \mu \mathrm{g} / \mathrm{mL}$ ); however, isolate 7 was tested 2 more times using Microscan, resulting in a value of $<2 \mu \mathrm{g} /$ $\mathrm{mL}$. Isolate 2 was not available for further analysis.

Within the genus Burkholderia, B. pseudomallei, B. mallei, and the $B$. cepacia complex are the species usually associated with human infection $(3,4)$. Historically, melioidosis is recognized as a major cause of fatal pneumonia and sepsis in Southeast Asia, South Asia, and northern Australia. It is believed that movements of both humans and cargo have contributed to the dissemination. A phylogenetic reconstruction study determined the African origin of the American isolates and the overlapping of the introduction of $B$. pseudomallei into the New World with the height of the slave trade from Africa to the Americas (5).

In Colombia, melioidosis is not a disease of public health interest and thus could be underreported. However,
Colombia is second to Brazil with the highest number of cases reported in South America (1). The actual number of cases is unknown, probably because of the lack of awareness and suspicion of the disease by health professionals, together with the absence of technology for proper diagnosis and the underreporting of diagnosed cases. At least 10 reported cases of melioidosis have been acquired in the Andean region of Colombia. Severiche published a report in 1998 about a patient with pneumonia (6). Montúfar et al. described a series of 7 patients during 1998-2012, of whom 5 had bacteremic pneumonia (7). Since then, other cases of bacteremic pneumonia have been reported $(8,9)$, as well as 1 case of chronic lung melioidosis in a patient on Colombia's west Caribbean coast (10). Guzmán-Gómez et al. described a case of osteoarticular melioidosis acquired in the Colombian rainforest in 2015 (11), the only case confirmed by sequencing (ITS-16S rRNA gene). The areas in Colombia where melioidosis cases have been reported, including these new cases from the Caribbean coast, are consistent with the previously proposed model (2) (Figure 1).

The isolation of $B$. pseudomallei from clinical specimens is the standard for a diagnosis of melioidosis. However, the microorganism is not often recovered and may not be correctly identified even when isolated. B. pseudomallei 
Table 2. Isolate identification results by commercial systems, $16 \mathrm{~S}$ rRNA sequencing analysis, and antimicrobial drug susceptibility of isolates of Burkholderia pseudomallei obtained from clinical specimens in the Caribbean coast region of Colombia*

\begin{tabular}{|c|c|c|c|c|c|c|c|c|c|}
\hline \multirow[b]{3}{*}{$\begin{array}{l}\text { Isolate } \\
\text { no. }\end{array}$} & \multicolumn{4}{|c|}{ Commercial bacterial identification systems } & \multirow[b]{3}{*}{$\begin{array}{l}\text { ITS sequencing } \\
\text { segments }\end{array}$} & \multirow{3}{*}{$\begin{array}{c}\text { GenBank } \\
\text { accession } \\
\text { no. }\end{array}$} & \multirow{2}{*}{\multicolumn{3}{|c|}{$\mathrm{MIC}, \mu \mathrm{g} / \mathrm{mL}$}} \\
\hline & & Walkaway/ & & & & & & & \\
\hline & $\begin{array}{l}\text { Vitek (\% } \\
\text { probability) }\end{array}$ & $\begin{array}{c}\text { Microscan (\% } \\
\text { probability) }\end{array}$ & $\begin{array}{c}\text { Phoenix } \\
\text { (\% probability) }\end{array}$ & $\begin{array}{l}\text { MALDI-TOF } \\
\text { MS (score) }\end{array}$ & & & CAZ & MER & $\begin{array}{l}\text { TMPI } \\
\text { SMX }\end{array}$ \\
\hline 1 & ND & $\begin{array}{c}\text { B. pseudomallei } \\
(93 \%)\end{array}$ & ND & ND & ND & ND & 2 & $\leq 1$ & $\leq 2 / 38$ \\
\hline 2 & $\begin{array}{c}\text { B. pseudomallei } \\
(99 \%)\end{array}$ & $\begin{array}{c}\text { B. pseudomallei } \\
(99.5 \%)\end{array}$ & ND & ND & ND & ND & $>16$ & $\leq 1$ & $\leq 2 / 38$ \\
\hline 3 & $\begin{array}{c}\text { B. pseudomallei } \\
(94 \%)\end{array}$ & $\begin{array}{c}\text { B. pseudomallei } \\
(99.8 \%)\end{array}$ & ND & ND & ND & ND & 2 & $\leq 1$ & $\leq 1 / 19$ \\
\hline 4 & $\begin{array}{c}\text { B. pseudomallei } \\
(94 \%)\end{array}$ & $\begin{array}{c}\text { B. pseudomallei } \\
(99.9 \%)\end{array}$ & $\begin{array}{l}\text { B. cepacia } \\
(99 \%)\end{array}$ & $\begin{array}{l}\text { B. thailandensis } \\
(1,899)\end{array}$ & B. pseudomallei & KX898558 & 4 & 1 & $2 / 38$ \\
\hline 5 & $\begin{array}{c}\text { B. pseudomallei } \\
(94 \%)\end{array}$ & $\begin{array}{c}\text { B. pseudomallei } \\
(99.5 \%)\end{array}$ & $\begin{array}{l}\text { B. cepacia } \\
(99 \%)\end{array}$ & B. thailandensis & B. pseudomallei & KY659330 & 4 & 2 & $1 / 19$ \\
\hline 6 & $\begin{array}{c}\text { B. pseudomallei } \\
(95 \%)\end{array}$ & $\begin{array}{c}\text { B. pseudomallei } \\
(99.9 \%)\end{array}$ & $\begin{array}{l}\text { B. cepacia } \\
(99 \%)\end{array}$ & B. thailandensis & B. pseudomallei & KY996759 & 4 & 1 & $1 / 19$ \\
\hline 7 & $\begin{array}{c}\text { B. pseudomallei } \\
(94 \%)\end{array}$ & $\begin{array}{c}\text { B. pseudomallei } \\
(93 \%)\end{array}$ & $\begin{array}{l}\text { B. cepacia } \\
(99 \%)\end{array}$ & $\begin{array}{c}\text { B. thailandensis } \\
(1,898)\end{array}$ & B. pseudomallei & KY659331 & $<2$ & 2 & $1 / 19$ \\
\hline
\end{tabular}

${ }^{*} \mathrm{CAZ}$, ceftazidime; ITS, internal transcribed spacer; MALDI-TOF MS, matrix-assisted laser desorption/ionization time-of-flight mass spectrometry; MER, meropenem; ND, no data; TMP/SMX, trimethoprim/sulfamethoxazole.

can be identified using commercial identification systems. However, these tests may fail to distinguish $B$. pseudomallei from $B$. thailandensis and other members of the B. cepacia complex $(12,13)$. MALDI-TOF mass spectrometry is an accurate and rapid procedure for the identification of $B$. pseudomallei if the appropriate database is used (14). However, genotyping methods based on rRNA sequencing should be used for a more accurate diagnosis. We compared different phenotyping methods (Vitek, MicroScan Walkaway, Phoenix, and MALDI-TOF mass spectrometry) using 4 isolates from this report. Sequencing of the ITS region confirmed the identification of B. pseudomallei and matched the identifications obtained by the Vitek and Walkaway systems. However, the Phoenix system erroneously identified isolates as B. cepacia, and MALDI-TOF mass spectrometry incorrectly identified isolates as $B$. thailandensis. Although B. pseudomallei was included in the Phoenix database, we strongly recommend not using Phoenix as a single or final method to identify possible isolates of B. pseudomallei (for example, gram-negative, oxidase-positive, and positive-arginine bacilli). MALDI-TOF mass spectrometry is currently being introduced in Colombia, and we recommend the inclusion of B. pseudomallei in the database.

The treatment of melioidosis is prolonged and includes 2 phases: intensive treatment with intravenous antimicrobial therapy for 10-14 days using ceftazidime, imipenem, or meropenem; and an eradication phase with oral antimicrobial therapy for 3-6 months with trimethoprim/sulfamethoxazole alone or in combination with doxycycline (15). In the cases we report, treatment with meropenem was started, because it is easier to prescribe this antimicrobial drug in Colombia, given the high rate of extendedspectrum $\beta$-lactamase-producing Enterobacteriaceae; the use of ceftazidime is restricted for the same reason. Because of the severity of illness and the high rate of death from this disease, along with the required prolonged antimicrobial drug therapy and the small number of drugs available for its treatment, it is necessary not only to strengthen the public health surveillance and clinical suspicion of melioidosis but also to acquire tools that permit an adequate diagnosis, especially in potentially endemic areas, which, in the case of Colombia, could be an extensive geographic area.

\section{Conclusions}

With the presence of $B$. pseudomallei on Colombia's Caribbean coast confirmed, clinicians should suspect melioidosis in patients with risk factors, suggestive clinical symptoms, and microbiological isolates from clinical specimens of B. pseudomallei or other members of the Burkholderia genus. In this case, $>1$ microbiological identification method should be used, especially if the outdated Phoenix or MALDI-TOF mass spectrometry databases are used.

Finally, it is necessary to include melioidosis in a passive surveillance system, especially in those regions of Latin America where the environmental conditions create high probabilities for the presence of the disease. Currently, Colombia has a public health surveillance and control system under the supervision of the National Institute of Health, to which all health institutions must notify diseases of public health interest. To determine the true magnitude of melioidosis in Colombia, it must be included as a notifiable disease and measures established to enable its early diagnosis and treatment.

\section{About the Author}

Dr. Rodríguez is chief of the Division of Infectious Diseases at the Instituto Cardiovascular del Cesar, Medicos Clinic, and Laura Daniela Clinic, Valledupar, Colombia. He is director and founder of Centro de Investigaciones Microbiológicas del Cesar, Valledupar, Colombia. His main research interest is nosocomial infections. 


\section{References}

1. Benoit TJ, Blaney DD, Doker TJ, Gee JE, Elrod MG, Rolim DB, et al. A review of melioidosis cases in the Americas. Am J Trop Med Hyg. 2015;93:1134-9. http://dx.doi.org/10.4269/ ajtmh.15-0405

2. Limmathurotsakul D, Golding N, Dance DAB, Messina JP, Pigott DM, Moyes CL, et al. Predicted global distribution of Burkholderia pseudomallei and burden of melioidosis. Nat Microbiol. 2016;1:15008. http://dx.doi.org/10.1038/ nmicrobiol.2015.8

3. Eberl L, Vandamme P. Members of the genus Burkholderia: good and bad guys. F1000 Res. 2016;5:1007. http://dx.doi.org/10.12688/ f1000research.8221.1

4. Depoorter E, Bull MJ, Peeters C, Coenye T, Vandamme P, Mahenthiralingam E. Burkholderia: an update on taxonomy and biotechnological potential as antibiotic producers. Appl Microbiol Biotechnol. 2016;100:5215-29. http://dx.doi.org/10.1007/ s00253-016-7520-x

5. Chewapreecha C, Holden MTG, Vehkala M, Välimäki N, Yang Z, Harris SR, et al. Global and regional dissemination and evolution of Burkholderia pseudomallei. Nat Microbiol. 2017;2:16263. http://dx.doi.org/10.1038/nmicrobiol.2016.263

6. Severiche D. Pseudomonas pseudomallei community acquired pneumonia. Rev Colomb Neumol. 1998;10:188-92.

7. Montúfar FE, Ochoa JE, Ortega H, Franco L, Montúfar MC, Monsalve A, et al. Melioidosis in Antioquia, Colombia: an emerging or endemic disease? A case series. Int J Infect Dis. 2015;37:50-7. http://dx.doi.org/10.1016/j.ijid.2015.05.023

8. Gonzalez G, Mantilla W, Rada R. Pneumonia and osteomyelitis by Burkholderia pseudomallei: report of a clinical case. Rev Med. 2009;17:146-9.

9. Osorio Carmona HE, Duran LF. Melioidosis: reporte de un caso en el departamento del Huila - Colombia. RFS Rev Fac Salud. 2014;6:56-9. http://dx.doi.org/10.25054/rfs.v6i2.166

10. Rosero CH, Gómez G, Gutiérrez OI. Tos y disnea de seis años de evolución en un adulto joven con melioidosis pulmonar crónica. Reporte de caso. Med Lab. 2013;19:465-72.

11. Guzmán-Gómez L, Agudo Bilbao M, Peiro-Callizo E, Salas C. Melioidosis importada desde Colombia a España. Enferm Infecc Microbiol Clin. 2015;33:214-6. http://dx.doi.org/10.1016/ j.eimc.2014.06.003

12. Lau SKP, Sridhar S, Ho C-C, Chow W-N, Lee K-C, Lam C-W, et al. Laboratory diagnosis of melioidosis: past, present and future. Exp Biol Med (Maywood). 2015;240:742-51. http://dx.doi.org/ $10.1177 / 1535370215583801$

13. Kiratisin P, Santanirand P, Chantratita N, Kaewdaeng S. Accuracy of commercial systems for identification of Burkholderia pseudomallei versus Burkholderia cepacia. Diagn Microbiol Infect Dis. 2007;59:277-81. http://dx.doi.org/10.1016/ j.diagmicrobio.2007.06.013

14. Wang H, Chen Y-L, Teng S-H, Xu Z-P, Xu Y-C, Hsueh P-R. Evaluation of the Bruker Biotyper matrix-assisted laser desorption/ionization time-of-flight mass spectrometry system for identification of clinical and environmental isolates of Burkholderia pseudomallei. Front Microbiol. 2016;7:415.

15. Kingsley PV, Arunkumar G, Tipre M, Leader M, Sathiakumar N. Pitfalls and optimal approaches to diagnose melioidosis. Asian Pac J Trop Med. 2016;9:515-24. http://dx.doi.org/10.1016/ j.apjtm.2016.04.003

Address for correspondence: José Y. Rodríguez, Centro de Investigaciones Microbiológicas del Cesar (CIMCE), Calle 16c no 19d-14 Barrio Dangond, Valledupar, Colombia; email: jyrodriguezq@gmail.com

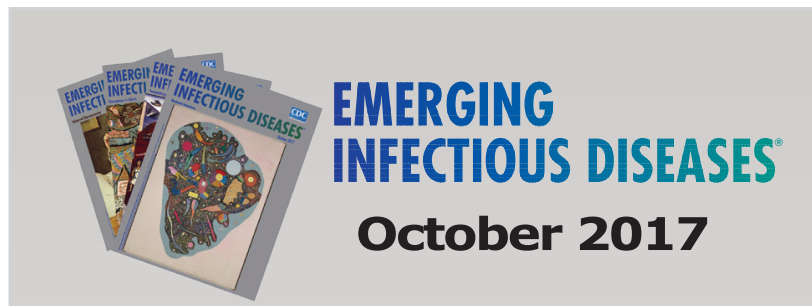

\section{Bacterial Infections}

- Fatal Rocky Mountain Spotted Fever along the United States-Mexico Border, 2013-2016

- Surveillance of Extrapulmonary Nontuberculous Mycobacteria Infections, Oregon, USA, 2007-2012

- Investigation of Outbreaks of Salmonella enterica Serovar Typhimurium and Its Monophasic Variants Using WholeGenome Sequencing, Denmark

- Enteric Infections Circulating during Hajj Seasons, 2011-2013

- Economic Assessment of Waterborne Outbreak of Cryptosporidiosis

- Antimicrobial Drug Prescription and Neisseria gonorrhoeae Susceptibility, United States, 2005-2013

- Poliovirus Excretion in Children with Primary Immunodeficiency Disorders, India

- Disease Burden of Clostridium difficile Infections in Adults, Hong Kong, China, 2006-2014

- Molecular Tracing to Find Source of Protracted Invasive Listeriosis Outbreak, Southern Germany, 2012-2016

- Dengue Virus 1 Outbreak in Buenos Aires, Argentina, 2016

- Mild Illness during Outbreak of Shiga Toxin-Producing Escherichia coli 0157 Infections Associated with Agricultural Show, Australia

- Enterovirus D68-Associated Acute Flaccid Myelitis in Immunocompromised Woman, Italy

- Diagnosis of Fatal Human Case of St. Louis Encephalitis Virus Infection by Metagenomic Sequencing, California, 2016

- Usutu Virus RNA in Mosquitoes, Israel, 2014-2015

- Macrolide-Resistant Mycoplasma pneumoniae Infection, Japan, 2008-2015

- Epidemiology of Reemerging Scarlet Fever, Hong Kong, 2005-2015

- Off-Label Use of Bedaquiline in Children and Adolescents with Multidrug-Resistant Tuberculosis

- Monitoring Avian Influenza Viruses from Chicken Carcasses Sold at Markets, China, 2016

- Berlin Squirrelpox Virus, a New Poxvirus in Red Squirrels, Berlin, Germany
To revisit the October 2017 issue, go to: https://wwwnc.cdc.gov/eid/articles/ issue/23/10/table-of-contents

